respond and hence provides a steady response to the overall air quality of a city, which may be described as 'slow-response exposure' but with chronic outcome. The consequences of chronic air pollution exposure are more serious in long term ${ }^{10}$. Results presented here may be helpful to policy makers to fine-tune guidelines for NAAQS and regulations to maintain a balance with economic development for progress of the nation.

1. Gufran Beig, S. K. et al., Objective evaluation of stubble emission of North India and quantifying its impact on air quality of Delhi. Sci. Total Environ., 2020; https://doi.org/10.1016/j.scitotenv. 2019.136126.

2. WHO, Glossary on Air Pollution, WHO Regional Publications, Europe Series No. 9, Regional Office for Europe, Copenhagen, Denmark, 1980

3. Pénard-Morand, C., Charpin, D., Raherison, C., Kopferschmitt, C., Caillaud, D., Lavaud, F. and Annesi-Maesano, I., Long-term exposure to background air pollution related to respiratory and allergic health in school children. Environ. Model. Softw, 2005, 35(10), 1279-1278.

4. Gómez-Losada, Á., Pires, J. C. M., Pino-Mejías, R., Modelling background air pollution exposure in urban environments: implications for epidemiological research. Environ. Model. Softw., 2018, 106, 13-21; https://doi.org/10.1016/j.envsoft.2018.02.011.

5. Beig, G. et al., System of Air Quality Forecasting and Research (SAFAR-India). GAW Report No. 217, World Meteorological Organization, Global Atmosphere Watch, Geneva, Switzerland, 2015.

6. Grimmond, S. et al., Establishing integrated weather, climate, water and related environmental services for megacities and large urban complexes - initial guidance, Global Framework for Climate Services, World Meteorological Organization, United Nations, Geneva, Switzerland, 2014.

7. Anand, V., Korhale, N., Rathod, A. and Beig, G., On processes controlling fine particulate matters in four Indian megacities. Environ. Pollut., 2019; doi:ENVPOL 2019 1529, 254 A, 113026.

8. http://pdf.directindustry.com/pdf/environnement-sa/mp101m-pm10-pm25-tsp-continuous-particulate-monitor/23554-578190.html (accessed on 3 April 2020).

9. Beig, G. et al., SAFAR-high resolution emission inventory of Megacity Delhi for 2018. Special Scientific Report, SAFARDelhi-2018-A, ISSN: 0252-1075, Indian Institute of Tropical Meteorology, Pune, 2018.

10. Menichini, E., Iacovella, N., Monfredini, F. and TurrioBaldassarri, L., Atmospheric pollution by PAHs, PCDD/Fs and PCBs simultaneously collected at a regional background site in central Italy and at an urban site in Rome. Chemosphere, 2007, 69 , $422-434$.

ACKNOWLEDGEMENTS. This work was supported by Indian Institute of Tropical Meteorology (IITM), Pune. We thank the Director, IITM and Secretary, Ministry of Earth Sciences for the support. Thanks are also due to the Delhi Pollution Control Committee. Sincere thanks to Dr Shailesh Nayak for motivating us to take up this challenging problem.

Received 20 May 2020; revised accepted 13 July 2020

doi: $10.18520 / \mathrm{cs} / \mathrm{v} 119 / \mathrm{i} 7 / 1178-1184$

\section{Economic incentives for sustainable legume production in India: a valuation approach internalizing risk sharing and environmental benefits}

\author{
Suresh Kumar ${ }^{1}$, Girish Kumar Jha ${ }^{1, *}$, \\ Dharam Raj Singh ${ }^{1}$ and H. Biswas ${ }^{2}$ \\ ${ }^{1}$ ICAR-Indian Agricultural Research Institute, \\ New Delhi 110 012, India \\ ${ }^{2}$ ICAR-Indian Institute of Soil and Water Conservation, \\ Research Centre, Bellary 583 104, India
}

The present study estimates the social cost of growing paddy, wheat and legumes as Rs 9484, 8804 and 1281 per ha respectively. Monetized value of overall risk in paddy, wheat and legumes is $R s$ 716, 650 and 1738 per ha respectively. An economic incentive consisting of risk and social benefits, to the tune of Rs 8611 and 9225 per ha over wheat and paddy respectively, should be provided for the production of legumes. The study highlights the need to internalize environmental benefits of legumes vis-à-vis competing crops, and accordingly cultivation of legumes needs to be encouraged through a proper mechanism of incentivization.

Keywords: Economic incentive, environmental benefits, legumes, risk sharing, rice, wheat.

INCLUSION of legumes in cropping systems makes the crop production system climate-change resilient, due to their ability to adapt to changing climatic conditions. This also helps in mitigating the impact of climate variability ${ }^{1}$. Moreover, legumes help in enhancing soil and human health $^{2}$. Taking cognizance of the contribution of legumes for sustainable food production and their role in eradicating hunger and malnutrition, the Food and Agriculture Organization, Rome, declared 2016 as the International Year of Pulses, and called for efforts towards promoting pulses. In spite of these efforts, it is observed that pulses are lagging behind cereals in terms of increase in area and productivity. This is mainly due to high yield variability in the production of legumes, and the preference of farmers for high-yielding cereal crops driven by skewed price support and cereal-centric policies ${ }^{3}$. It was pointed out that horizontal area expansion of $2.65 \mathrm{~m}$ ha in the Indo-Gangetic Plains (IGP) is possible by inclusion of legumes as sequential, mixed or inter-crops in different cropping systems ${ }^{4}$. However, the benefits of such arrangements need to be vigorously pursued with farmers and policymakers, who often ignore the long-term benefits and focus instead on short-term returns. This leads to an underestimation and thus under-valuation of ecosystem services provided by legumes. With the prevailing

*For correspondence. (e-mail: girish.stat@gmail.com) 


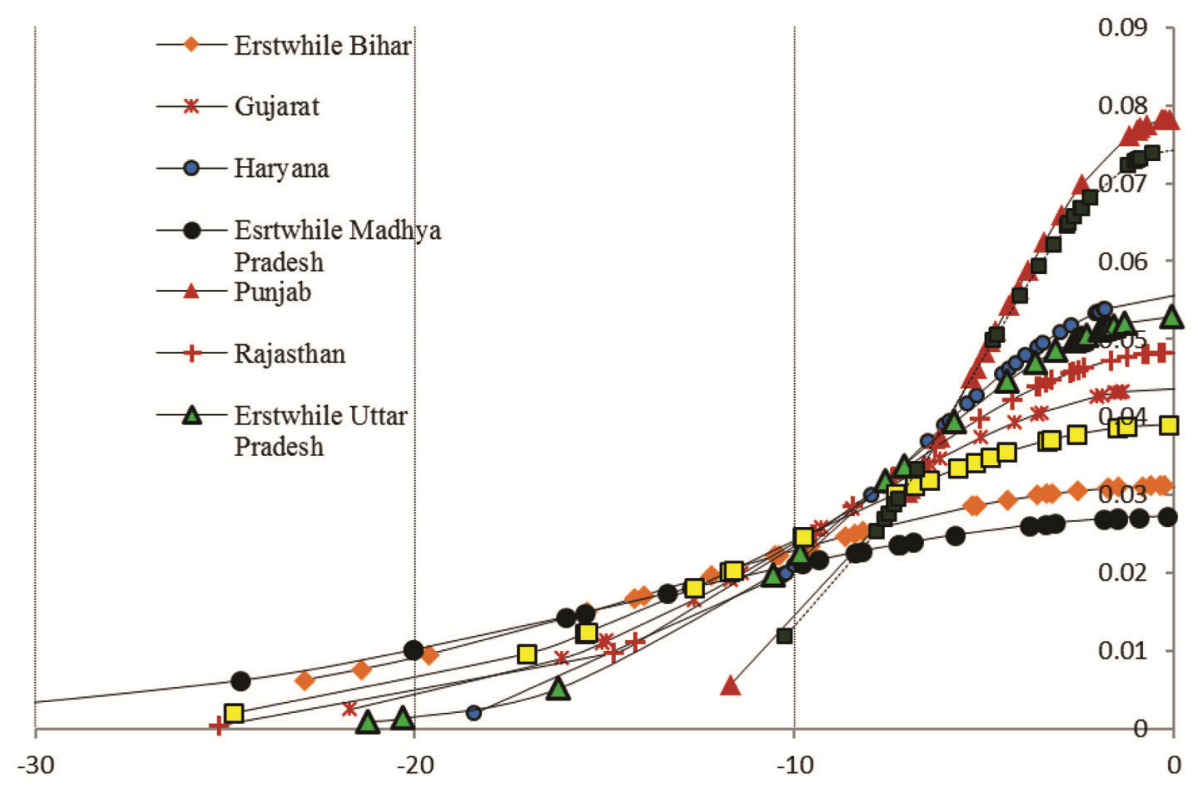

Figure 1. Probability distribution curve of normalized negative anomalies of wheat yield.

disincentivizing factors, the expansion in area under pulses can be achieved by increasing relative profitability in comparison to competing crops, particularly dominant cereals $^{3}$. As a matter of fact, ecosystem services/ environmental benefits provided by pulses are shared by the society in terms of savings of water and fertilizers, and subsidies thereupon, relatively less greenhouse gas (GHG) emission, etc. However, the risks associated with the cultivation of pulses are borne by the farmers alone. We hypothesize that if the cultivation of pulses is to be incentivized, its environmental benefits and associated risks are to be considered while formulating an incentive plan for encouraging farmers to expand the area under pulses. For this, quantification of risks in the production of pulses, and valuation of environmental benefits of pulses are required, which are the underlying objectives of the present study. The estimated risk and value of benefits will help in guiding policymakers and planners for incentivizing and promoting pulse-based sustainable crop production systems.

In this study, risk is measured as the expected yield loss which is computed as the mean of yield anomaly that is higher than a defined negative deviation. Yield data for major pulses (chickpea, pigeon pea, green gram, lentils and black gram), paddy and wheat for the major growing states were obtained from the Directorate of Economics and Statistics, Government of India, for the period 1970 2016. During this period, some states were reorganized and new states were carved out of the old ones. However, we have considered erstwhile states, namely Andhra Pradesh, Bihar, Madhya Pradesh and Uttar Pradesh for this study. For estimating yield trend for each crop and state, the polynomial regression models, viz. linear, quadratic and cubic as shown in eqs (1)-(3) respectively, were fitted to the observed data, and the best model was selected using the least Akaike Information Criterion (AIC; eq. (4)) value.

$$
\begin{aligned}
& Y_{t}=\alpha+\beta T_{t}+\varepsilon_{t}, \\
& Y_{t}=\alpha+\beta T_{t}+\gamma T_{t}^{2}+\varepsilon_{t}, \\
& Y_{t}=\alpha+\beta T_{t}+\gamma T_{t}^{2}+\delta T_{t}^{3}+\varepsilon_{t},
\end{aligned}
$$

where $Y_{t}$ is the yield of a crop in year $t\left(\mathrm{~kg} \mathrm{ha}^{-1}\right), t$ the year index (with $t=1$ for the year 1970), $\varepsilon_{t}$ the residual with zero mean and constant variance, and $\alpha, \beta, \gamma$ and $\delta$ are the parameters of the polynomial regression model.

$$
\mathrm{AIC}=-2(\log -\text { likelihood })+2 K,
$$

where $K$ is the number of model parameters. The predicted yield values $\left(\hat{Y}_{t}\right)$ were obtained using the best-fitted model. Then a yield anomaly was computed using the difference between observed and predicted yield values (i.e. yield residual). Yield anomalies were normalized using the predicted values in order to compare anomalies across crops, and converted into percentage as given in eq. (5)

$$
\bar{Y}_{t}=\frac{Y_{t}-\hat{Y}_{t}}{\hat{Y}_{t}} \times 100 .
$$

For computing the risk of pulses, wheat was selected as a reference because of being the most stable crop in terms of yield stability (minimum year-to-year variability), as $94 \%$ of the cropped area is being grown with assured 
irrigation facility ${ }^{5}$. As indicated, only negative yield anomalies, which lead to loss of production, were considered for estimating the risk. It was observed that during most years, negative normalized yield anomalies in case of wheat remained within $-10 \%$ (Figure 1 ). Therefore, in this study, risk is defined as the mean of yield anomalies that is higher than $-10 \%$ of anomalies. This risk is known as the expected yield loss (EYL; $\mathrm{kg} \mathrm{ha}^{-1}$ ) and is computed as

$$
\mathrm{EYL}=\left\{\begin{array}{c}
\frac{T * \sum_{i=1}^{T^{*}}\left(Y_{t}-\hat{Y}_{t}\right)}{T}, \text { if }\left(\frac{\left(Y_{t}-\hat{Y}_{t}\right)}{\hat{Y}_{t}}\right) \times 100 \leq-10 \% \\
0
\end{array}\right. \text { otherwise }
$$

where $T^{*}$ is the number of years when negative anomaly goes beyond $-10 \%$ and $T$ is the total number of years, i.e. 47 years from 1970 to 2016. Frequency of deviations beyond $-10 \%$ was used to compute the probability of yield anomaly. The monetary value of expected yield loss (MEYL; Rs ha ${ }^{-1}$ ) was obtained by multiplying EYL with minimum support price (MSP)

$$
\text { MEYL }=\mathrm{EYL} \times \text { MSP. }
$$

For computing overall risk at the national level, the percentage share of each state in the total area was used as weights. EYL and MEYL represent risks in physical and monetary terms respectively. Based on the value of expected risk, the states were classified into three categories, viz. high, medium and low level of risk using percentile.

Incorporation of pulses in the cropping system has multiple benefits. Chiefly, they fix atmospheric nitrogen in the soil and therefore, there is a relatively less need of application of nitrogenous fertilizers. This reduces the risk of environmental damage associated with fertilizer applications and helps reduce $\mathrm{N}_{2} \mathrm{O}$ emissions in comparison to other crops ${ }^{6}$. Further, pulses have a desirable positive impact on soil health as they increase the availability of nutrients, help in carbon sequestration, and improve soil structure. They also help in maintaining soil biodiversity, and thereby build resilience of soil to climate change ${ }^{7}$. Pulses save water (higher water-use efficiency, which is almost five times more than for cereals) and synthetic fertilizers, thereby leading low GHG emission and help save electricity and fertilizer subsidies ${ }^{2,8}$. Despite these benefits, markets fail to translate positive effects of legumes into economic benefits ${ }^{9}$.

The benefits of pulses have been computed in terms of subsidy savings on fertilizers and irrigation, and value of nitrogen-fixed.

For estimating social/environmental benefits of pulses over wheat and paddy, plot-level summary data on the cost of cultivation (TE 2013-14) were used to compute the level of input $(\mathrm{N}, \mathrm{P}, \mathrm{K}$, irrigation hours and farm machine hours) utilization pattern. Data on fertilizer and electricity subsidy were taken from the Fertilizer Association of India (2014-15) and Power Finance Corporation Limited (2015-16) respectively. Using the conversion factors for carbon equivalent emission (CEE), i.e. 1.3, $0.2,0.15,0.94$ and $0.94 \mathrm{~kg} \mathrm{CE} \mathrm{kg}^{-1}$ of nitrogen, phosphorus, potassium, electricity and diesel respectively, the global warming potential (GWP) was computed as: $\mathrm{CEE}=\mathrm{GWP} \times$ 12/44 (refs 10, 11). Emissions from field conditions in terms of GWP were taken as $210 \mathrm{~kg} \mathrm{CO}_{2}$ per ha for pulses, $3110 \mathrm{~kg} \mathrm{CO}_{2} \mathrm{ha}^{-1}$ for wheat and $1719 \mathrm{~kg} \mathrm{CO}_{2} \mathrm{ha}^{-1}$ for rice ${ }^{12,13}$. The electricity charges for irrigating crops were estimated using the formula: Horsepower $\times 0.746 \times$ irrigation hours $\times \%$ electrified pumps $\times$ subsidy per unit of energy. Further social/environmental cost was computed as: Social/environmental cost $\left(\mathrm{Rs} \mathrm{ha}{ }^{-1}\right)=$ cost of irrigation subsidy + cost of fertilizer subsidy + value of carbon credit for GHG emission (due to use of fertilizer, electricity and farm machinery) - value of nitrogen fixation. According to our hypothesis, the value of incentive for pulses is: Incentive ( $\left.\mathrm{Rs} \mathrm{ha}^{-1}\right)=$ benefits of pulses over wheat/paddy + MEYL in pulses over wheat/paddy.

Tables 1 and 2 give the FYL $\left(\mathrm{kg} \mathrm{ha}^{-1}\right)$ and MEYL (Rs $\mathrm{ha}^{-1}$ ) respectively. The EYL ranged between 95 and $208 \mathrm{~kg} \mathrm{ha}^{-1}$ in chickpea. It was found to be highest in Haryana followed by erstwhile Uttar Pradesh $\left(180 \mathrm{~kg} \mathrm{ha}^{-1}\right)$. Further, probability of risk ranged between 0.13 and 0.36 . The highest expected monetary risk was (Rs $2923 \mathrm{ha}^{-1}$ ) in Haryana, followed by erstwhile Andhra Pradesh (Rs $\left.2206 \mathrm{ha}^{-1}\right)$. In the major chickpea-producing states, namely erstwhile Madhya Pradesh, Maharashtra, Rajasthan, Karnataka, erstwhile Andhra Pradesh and erstwhile Uttar Pradesh, which account for more than $90 \%$ of total area under the crop, the probability of risk was $0.15,0.23$, $0.32,0.26,0.30$ and 0.21 respectively.

The chance of risk-proneness in pulses (probability ratio) was 2-3 times higher than that of wheat. The extent of risk (MEYL ratio) was roughly 2-4 times more in pulses in comparison to wheat (last two rows of Table 2). In fact, farmers make decisions relating to allocation of area under a crop considering the expected profitability and availability of the required resources, particularly irrigation. Additionally, farmers also factor in the level of risk, particularly in rainfed areas. Therefore, higher level of risk in pulses may outweigh the profit expected from the increased prices. However, farmers in general do not realize the incremental change in prices due to inherent market-related weakness. Therefore, higher level of risk may be the reason for rigidness of acreage response to increasing minimum support price (MSP). To put it simply, the increased price also increases the level of expected risk, which is a linear function of prices. Therefore, at the same level of productivity, increased prices and thereby increased level of risk render pulses worse-off in comparison to competing crops, especially cereals. 
RESEARCH COMMUNICATIONS

Table 1. Expected yield loss and probability of risk in pulses in different states $\left(\mathrm{kg} \mathrm{ha}^{-1}\right)$

\begin{tabular}{|c|c|c|c|c|c|c|}
\hline State & Wheat & Chickpea & Pigeon pea & Green gram & Lentils & Black gram \\
\hline Erstwhile Andhra Pradesh & - & $168(0.30)$ & $77(0.28)$ & $111(0.30)$ & - & $146(0.26)$ \\
\hline Erstwhile Bihar & $271(0.19)$ & $142(0.21)$ & $204(0.30)$ & $76(0.19)$ & $137(0.26)$ & $97(0.19)$ \\
\hline Erstwhile Madhya Pradesh & $298(0.17)$ & $146(0.15)$ & $173(0.32)$ & $102(0.13)$ & $126(0.15)$ & $67(0.21)$ \\
\hline Erstwhile Uttar Pradesh & $347(0.9)$ & $180(0.21)$ & $219(0.26)$ & $78(0.36)$ & $112(0.21)$ & $92(0.26)$ \\
\hline Gujarat & $334(0.15)$ & $170(0.28)$ & $210(0.21)$ & - & - & $148(0.19)$ \\
\hline Haryana & $358(0.9)$ & $208(0.32)$ & $234(0.26)$ & $156(0.36)$ & $116(0.19)$ & $139(0.30)$ \\
\hline Karnataka & $192(0.23)$ & $117(0.26)$ & $132(0.28)$ & $87(0.43)$ & - & $94(0.47)$ \\
\hline Maharashtra & $200(0.26)$ & $122(0.23)$ & $166(0.26)$ & $103(0.34)$ & $80(0.34)$ & $109(0.34)$ \\
\hline Odisha & - & $104(0.13)$ & $134(0.21)$ & $99(0.26)$ & - & $75(0.21)$ \\
\hline Punjab & $393(0.2)$ & $162(0.28)$ & $160(0.23)$ & $155(0.23)$ & $227(0.17)$ & $87(0.19)$ \\
\hline Rajasthan & $327(0.6)$ & $126(0.32)$ & $178(0.40)$ & $123(0.43)$ & $152(0.23)$ & $139(0.34)$ \\
\hline Tamil Nadu & - & $95(0.17)$ & $130(0.36)$ & $110(0.34)$ & - & $118(0.32)$ \\
\hline West Bengal & $329(0.15)$ & $158(0.21)$ & - & $105(0.30)$ & $145(0.26)$ & $108(0.19)$ \\
\hline Assam & - & $121(0.36)$ & - & - & - & - \\
\hline Himachal Pradesh & $345(0.30)$ & - & - & - & - & $87(0.34)$ \\
\hline Jammu and Kashmir & $397(0.21)$ & - & - & - & - & - \\
\hline Overall & $329(0.11)$ & $139(0.22)$ & $156(0.27)$ & $108(0.34)$ & $126(0.20)$ & $101(0.26)$ \\
\hline
\end{tabular}

Figures in parentheses are probability of risk. - Indicates that data is not available.

Table 2. Monetary value of expected yield loss (MEYL) in pulses in different states ( $\left.\mathrm{Rs} \mathrm{ha}^{-1}\right)$

\begin{tabular}{|c|c|c|c|c|c|c|c|}
\hline State & Wheat & Paddy & Chickpea & Pigeon pea & Green gram & Lentils & Black gram \\
\hline Erstwhile Andhra Pradesh & - & 404 & 2206 & 1213 & 2301 & - & 2093 \\
\hline Erstwhile Bihar & 900 & 1362 & 1329 & 3452 & 1017 & 1487 & 1040 \\
\hline Erstwhile Madhya Pradesh & 879 & 978 & 958 & 3125 & 912 & 796 & 797 \\
\hline Erstwhile Uttar Pradesh & 513 & 600 & 1685 & 3167 & 1968 & 1017 & 1314 \\
\hline Gujarat & 864 & 1515 & 2066 & 2531 & - & - & 1589 \\
\hline Haryana & 528 & 935 & 2923 & 3392 & 3927 & 942 & 2316 \\
\hline Karnataka & 779 & 628 & 1314 & 2075 & 2585 & - & 2473 \\
\hline Maharashtra & 885 & 1251 & 1259 & 2404 & 2440 & 1164 & 2073 \\
\hline Odisha & - & 1244 & 586 & 1613 & 1764 & - & 894 \\
\hline Punjab & 145 & 429 & 1972 & 2124 & 2534 & 1643 & 937 \\
\hline Rajasthan & 362 & - & 1769 & 4088 & 3655 & 1514 & 2656 \\
\hline Tamil Nadu & - & 2735 & 713 & 2659 & 2610 & - & 2100 \\
\hline West Bengal & -849 & 674 & 1477 & - & 2171 & 1568 & 1156 \\
\hline Assam & - & 463 & 1926 & - & - & - & - \\
\hline Himachal Pradesh & 1784 & - & - & - & - & - & 1667 \\
\hline Jammu and Kashmir & 1467 & - & - & - & - & - & - \\
\hline Overall & 650 & 716 & 1336 & 2535 & 1048 & 2414 & 1487 \\
\hline \multicolumn{8}{|c|}{ Overall risk (in comparison to wheat) } \\
\hline MEYL ratio & & - & 2.06 & 3.90 & 1.61 & 3.71 & 2.29 \\
\hline Probability ratio & & - & 2.0 & 2.5 & 3.1 & 1.8 & 2.4 \\
\hline
\end{tabular}

- Indicates that data is not available. MEYL ratio and probability ratio represent the ratio of MEYL and probability of risk of pulses over wheat respectively. 
RESEARCH COMMUNICATIONS

Table 3. Classification of states based on expected monetary value of risk in pulses

\begin{tabular}{|c|c|c|c|c|c|}
\hline Category & Chickpea & Pigeon pea & Green gram & Lentils & Black gram \\
\hline High & $\begin{array}{l}\text { Haryana, Erstwhile } \\
\text { Andhra Pradesh, } \\
\text { Gujarat, Punjab, } \\
\text { Assam }\end{array}$ & $\begin{array}{l}\text { Rajasthan, Erstwhile Bihar, } \\
\text { Haryana, Erstwhile Uttar } \\
\text { Pradesh }\end{array}$ & $\begin{array}{l}\text { Haryana, Rajasthan, } \\
\text { Tamil Nadu, Karnataka }\end{array}$ & $\begin{array}{l}\text { Punjab, West Bengal, } \\
\text { Rajasthan }\end{array}$ & $\begin{array}{l}\text { Rajasthan, Karnataka, } \\
\text { Haryana, Tamil Nadu, } \\
\text { Erstwhile Andhra } \\
\text { Pradesh }\end{array}$ \\
\hline Medium & $\begin{array}{l}\text { Rajasthan, Erstwhile } \\
\text { Uttar Pradesh, } \\
\text { West Bengal, } \\
\text { Erstwhile Bihar, } \\
\text { Karnataka }\end{array}$ & $\begin{array}{l}\text { Erstwhile Madhya } \\
\text { Pradesh, Tamil } \\
\text { Nadu, Gujarat, } \\
\text { Maharashtra }\end{array}$ & $\begin{array}{l}\text { Punjab, Maharashtra, } \\
\text { Erstwhile Andhra } \\
\text { Pradesh, West } \\
\text { Bengal }\end{array}$ & $\begin{array}{l}\text { Erstwhile Bihar, } \\
\text { Maharashtra }\end{array}$ & $\begin{array}{l}\text { Maharashtra, Himachal } \\
\text { Pradesh, Gujarat, } \\
\text { Erstwhile Uttar Pradesh }\end{array}$ \\
\hline Low & $\begin{array}{l}\text { Maharashtra, Erstwhile } \\
\text { Madhya Pradesh, } \\
\text { Tamil Nadu, Odisha }\end{array}$ & $\begin{array}{c}\text { Punjab, Karnataka, } \\
\text { Odisha, Erstwhile } \\
\text { Andhra Pradesh }\end{array}$ & $\begin{array}{l}\text { Erstwhile Uttar Pradesh, } \\
\text { Odisha, Erstwhile } \\
\text { Bihar, Erstwhile } \\
\text { Madhya Pradesh }\end{array}$ & $\begin{array}{l}\text { Erstwhile Uttar } \\
\text { Pradesh, Haryana, } \\
\text { Erstwhile Madhya } \\
\text { Pradesh }\end{array}$ & $\begin{array}{l}\text { West Bengal, Erstwhile } \\
\text { Bihar, Punjab, Odisha, } \\
\text { Erstwhile Madhya } \\
\text { Pradesh }\end{array}$ \\
\hline
\end{tabular}

Table 4. Summary of inputs utilization and greenhouse gas emission per ha

\begin{tabular}{lccc}
\hline Crop & Irrigation $(\mathrm{h})$ & $\mathrm{NPK}(\mathrm{kg})$ & $\begin{array}{c}\text { Global warming potential } \\
(\mathrm{GWP} ; \mathrm{kg} \mathrm{CO})_{2}\end{array}$ \\
\hline Paddy & 104 & 142 & 5867 \\
Wheat & 76 & 164 & 3835 \\
Pulses & 4.3 & 40 & 727 \\
\hline
\end{tabular}

Irrigation hours and NPK utilization are weighted average of the statelevel utilization; share in the total area is used as weights. For GWP, median values were considered ${ }^{12}$.

Based on the quantum of expected risk, Haryana, erstwhile Andhra Pradesh, Gujarat, Punjab and Assam were classified under the high-risk category, whereas Rajasthan, erstwhile Uttar Pradesh, West Bengal and erstwhile Bihar were classified in the medium risk category in terms of chickpea yield. Further, around 43\% area under chickpea was under the high to medium risk category (Table 3 ). At the national level, the average risk for chickpea production was computed as $139 \mathrm{~kg} \mathrm{ha}^{-1}$, which is equivalent Rs $1336 \mathrm{ha}^{-1}$. In case of pigeon pea, the expected risk was in the range $77-234 \mathrm{~kg} \mathrm{ha}^{-1}$ across different states. Relatively higher risk values (greater than $200 \mathrm{~kg} \mathrm{ha}^{-1}$ ) were obtained in erstwhile Bihar, erstwhile Uttar Pradesh, Gujarat and Haryana. Probability of risk varied between 0.21 and 0.40 overall, while in the major pigeon pea-producing states of Maharashtra, Karnataka, erstwhile Madhya Pradesh and erstwhile Andhra Pradesh, sharing around three-fourths of the total area under pigeon pea, the probability of risk varied from 0.26 to 0.32 . The expected monetary risk in pigeon pea was found to be highest in Rajasthan (Rs $4088 \mathrm{ha}^{-1}$ ) followed by erstwhile Bihar (Rs $3452 \mathrm{ha}^{-1}$ ). In case of pigeon pea, Rajasthan, erstwhile Bihar, Haryana and erstwhile Uttar Pradesh were placed in the high-risk category. Around $65 \%$ area under pigeon pea was prone to high to medium risk levels. At the country level, the expected physical risk, probability of risk and expected monetary risk in pigeon pea production were $156 \mathrm{~kg} \mathrm{ha}^{-1}, 0.27$ and Rs $2414 \mathrm{ha}^{-1}$ respectively. In Punjab and Haryana, efforts have been made to diversify the cropping system by introducing pulses, particularly pigeon pea in place of paddy. However, no noticeable success could be achieved, which can be attributed to higher risk to the tune of Rs $2457 \mathrm{ha}^{-1}$, which is higher than for paddy (Rs $1695 \mathrm{ha}^{-1}$ ). In case of green gram, higher average risk (more than $150 \mathrm{~kg} \mathrm{ha}^{-1}$ ) was reported in Haryana followed by Punjab. However, higher probability of the risk (0.43) was observed in Rajasthan and Karnataka which have a sizable share (more than $40 \%$ of the total area) in green-gram production. The highest expected monetary risk in green gram was in Haryana (Rs $3927 \mathrm{ha}^{-1}$ ) followed by Rajasthan (Rs $3655 \mathrm{ha}^{-1}$ ). Further, more than half of the total area under green gram was in the highrisk category. At the national level, the expected monetary risk in green gram was computed as Rs $1048 \mathrm{ha}^{-1}$. Similarly, the average physical risk in lentils ranged between 80 and $227 \mathrm{~kg} \mathrm{ha}^{-1}$. Overall, at the national level, the expected monetary risk for the production of lentils was Rs $2414 \mathrm{ha}^{-1}$. In case of black gram, the highest expected monetary risk attributed to yield loss occurred in Rajasthan (Rs $2656 \mathrm{ha}^{-1}$ ), followed by Karnataka (Rs $2473 \mathrm{ha}^{-1}$ ). The values of expected physical and monetary risk across the country were worked out to be $101 \mathrm{~kg} \mathrm{ha}^{-1}$ and Rs $1487 \mathrm{ha}^{-1}$ respectively.

On an average, rice, wheat and pulses are given 104, 76 and $4.3 \mathrm{~h}$ of irrigation, whereas $\mathrm{N}, \mathrm{P}$ and $\mathrm{K}$ consumption is around 142,164 and $40 \mathrm{~kg} \mathrm{ha}^{-1}$ respectively. The total GWP of paddy, wheat and pulses are 5867, 3835 and $727 \mathrm{~kg} \mathrm{CO}_{2} \mathrm{ha}^{-1}$ respectively (Table 4). At the national level, the social cost of paddy, wheat and pulses has been worked out to be Rs 9484, 8804 and 1281 per ha respectively (Table 5). Relative social benefits of pulses in comparison to wheat and paddy are Rs 7523 and $8203 \mathrm{ha}^{-1}$ respectively. Analysis shows that legumes are prone to 
RESEARCH COMMUNICATIONS

Table 5. Environmental/social cost, risk in pulses and economic incentive over wheat and paddy $\left(\mathrm{Rs} \mathrm{ha}^{-1}\right)$

\begin{tabular}{lrrrrr}
\hline Particulars & Paddy & Wheat & Pulses & Benefits over wheat & Benefits over paddy \\
\hline NPK subsidy & -4179 & -4814 & -1176 & 3638 & 3003 \\
Groundwater subsidy & -1048 & -1208 & -27 & 1181 & 1021 \\
GHG emission & -4257 & -2782 & -528 & 2254 & 3729 \\
N-fixation & 0 & 0 & 450 & 450 & 450 \\
Environmental/social cost per ha & -9484 & -8804 & -1281 & 7523 & 8203 \\
Monetary value of expected risk & 716 & 650 & 1738 & 1088 & 1022 \\
Economic incentive for pulses & & & & 8611 & 9225 \\
\hline
\end{tabular}

Value of carbon credit is taken as Rs 725.6. Subsidy for NPK is Rs 29 per kg.

risk to the tune of Rs 1088 and $1022 \mathrm{ha}^{-1}$ over the wheat and paddy respectively. Therefore, considering both relative risk as well as benefits of legumes, around Rs 8611 and $9225 \mathrm{ha}^{-1}$ must be given as incentive over wheat and paddy respectively.

In this study, risk in the production of legumes has been highlighted as one of the key factors leading to stagnation in the area under legumes. For instance, chickpea cultivation is around 4.9, 1.1, and 3.29, 13.6 and 5.54 times riskier than wheat production in Rajasthan, Madhya Pradesh, Uttar Pradesh, Punjab and Haryana respectively. We also advocate that relative risk and environmental benefits of legumes should be internalized, for incentivizing pulse production to the tune of Rs 8611 and 9225 per ha over wheat and paddy respectively, which will make the legumes competitive. Policy implication of our findings is that there is a need to internalize the environmental benefits of legumes vis-à-vis competing crops and/or in comparison to other crops in areas wherein diversification is required to sustain the natural resources as well as harness the multiple benefits of legumes.

1. FAO, Pulses and climate change. Food and Agriculture Organization of the United Nations, Rome, Italy, 2016; http://www.fao.org/ fileadmin/user upload/pulses-2016/docs/factsheets/Climate EN PRINT.pdf.

2. Lal, R., Improving soil health and human protein nutrition by pulses-based cropping systems. Adv. Agron., 2017, 145, 167-204.

3. McDermott, J. and Wyatt, A. J., The role of pulses in sustainable and healthy food systems. Ann. NY Acad. Sci., 2017, 1392(1), 3042.

4. Singh, K. K., Ali, M. and Venkatesh, M. S., Pulses in Cropping Systems, Technical Bulletin. ICAR-Indian Institute of Pulse Research, Kanpur, 2009, p. 39; https://iipr.icar.gov.in/pdf/pulses in cropping systems.pdf

5. Chand, R. and Raju, S. S., Instability in Indian agriculture during different phases of technology and policy. Indian J. Agric. Econ., 2009, 64(2), 187-207.

6. Dequiedt, B. and Moran, D., The cost of emission mitigation by legume crops in French agriculture. Ecol. Econ., 2015, 110, 5160.

7. Singh, V. K., Sharma, B. B. and Dwivedi, B. S., The impact of diversification of a rice-wheat cropping system on crop productivity and soil fertility. J. Agric. Sci., 2002, 139(4), 405-412.

8. Pande, S., Sharma, M. and Ghosh, R., Role of pulses in sustaining agricultural productivity in the rainfed rice-fallow lands of India in changing climatic scenario. 2012, 5370; http://oar.icrisat.org/ 6150/1/Role_of_pulses_spande et.al.2012.pdf

9. Zander, P. et al., Grain legume decline and potential recovery in European agriculture: a review. Agron. Sustain. Dev., 2016, 36, 26.

10. Lal, R., Carbon emission from farm operations. Environ. Int., 2004, 30(7), 981-990.

11. Bhatia, A., Pathak, H., Jain, N., Singh, P. K. and Singh, A. K., Global warming potential of manure amended soils under ricewheat system in the Indo-Gangetic plains. Atmos. Environ., 2005, 39(37), 6976-6984.

12. Pathak, H., Bhatia, A. and Jain, N., Greenhouse Gas Emission from Indian Agriculture: Trends, Mitigation and Policy Needs. Indian Agricultural Research Institute, New Delhi, 2014, p. 39; https://krishi.icar.gov.in/jspui/bitstream/123456789/32431/1/GreenhouseGasEmissionfromIndianAgricultureHPathaketal\%20\%281\%29. pdf

13. Bhatia, A., Jain, N. and Pathak, H., Methane and nitrous oxide emissions from Indian rice paddies, agricultural soils and crop residue burning. Greenhouse Gases: Sci. Technol., 2013, 3(3), 196-211.

Received 20 February 2020; revised accepted 6 July 2020

doi: $10.18520 / \mathrm{cs} / \mathrm{v} 119 / \mathrm{i} 7 / 1184-1189$ 